\title{
Management Strategy of Bleeding Pelvic Fracture
}

\author{
Byung Chul Yu, Min Chung \\ Department of Trauma Surgery, Gachon University Gil Medical Center, Incheon, Korea
}

\begin{abstract}
Although there have been some improvements in mortality and morbidity associated with bleeding pelvic fractures, patients with unstable pelvic fracture are still a therapeutic challenge for the trauma surgeon. Outcomes may be improved through multidisciplinary approaches to control hemorrhage and temporarily stabilize the fracture. Angioembolization has been successfully used for decades but there are some limitations. Recently, pelvic stabilization with extraperitoneal pelvic packing was introduced as an alternative or adjunctive therapy. Appropriate management algorithm is needed to successfully manage patients with pelvic bone fracture.
\end{abstract}

(Trauma Image Proced 2016(1):1-6)

Key Words: Hemorrhage; Pelvis; Fractures, Bone; Therapy

\section{서 론}

출혈성 골반골절은 외상체계가 잘 갖추어진 나 라에서도 치료가 어려운 중증외상으로 $40 \%$ 까지 높은 사망률이 보고되고 있다 $(1,2)$. 불안정 골반 골절은 대부분 고에너지 둔상으로 발생하여 동반 손상이 많고 대량 출혈이 동반되는 경우가 흔하다. 이러한 출혈성 골반골절의 치료에는 다학제적 접 근이 중요한데, 다학제적 접근은 응급실/외상소생 실부터 혈관 조영실, 수술실 그리고 중환자실에 이 르는 전 과정에서 적절하게 이루어져야 한다.

출혈성 골반골절에서 동맥출혈은 혈관색전술로 치 료가 가능하다 (3). 골절면에서의 출혈은 수술을 통환 골반 외고정이나 골반 바인더등의 외부 압박으로 지 혈을 시도할 수 있다 $(4,5)$. 수술실 또는 응급실에서 할 수 있는 외복막 거즈 충전술(Extraperitoneal pelvic packing: EPP)은 골절면 및 정맥출혈에 효과적이라고 최근 보고되고 있으며, 미국의 몇몇 센터에서 활발히
시행하고 있다 (6). 최근에는 REBOA (Resuscitative Endovascular Balloon Occlusion of the Aorta)가 소개되 면서 골반골절에 적용하려는 보고들이 있다 (7).

다학제적 접근이 가능하기 위해서는 골반골절의 진단, 치료 방법에 대해 서로 공유하고 각 기관의 자 원에 알맞은 적절한 치료 알고리즘이 기반이 되어야 한다. 초기 소생술과 진단에 대해서는 대체로 지금까 지 제시된 가이드라인들에 많은 센터들이 동의하고 있지만 최근 소개되고 있는 치료방법들에 대해서는 여전히 논란이 있다. 중증외상 환자들은 환자수가 충 분하지 않고 여러가지 제한점으로 인해 전향적 무작 위 배정 연구는 시행하기 어렵다. 따라서 각 기관에 서는 각각의 치료법들에 대해 이해하고 장단점을 파 악하고 있어야 하겠다. 저자들은 앞서 기술한 출혈성 골반골절에 대한 치료법을 소개하고 최근의 치료 경 향을 살펴 보고자 한다.

Received: April 13, 2016 Revised: May 2, 2016 Accepted: May 2, 2016

Correspondence to: Min Chung, Department of Trauma Surgery, Gachon University Gil Medical Center, 21, Namdon-daero, 774 Beon-gil, Namdong-gu, Incheon 21565, South Korea

Tel: 82-32-460-3010, Fax: 82-32-460-2372, E-mail: mc@gilhospital.com

Copyright (c) 2016 Korean Association for Research, Procedures and Education on Trauma. All rights reserved.

@) This is an open-access article distributed under the terms of the Creative Commons Attribution Non-Commercial License (http://creativecommons.org/ licenses/by-nc/4.0) which permits unrestricted noncommercial use, distribution, and reproduction in any medium, provided the original work is properly cited 


\section{본 론}

\section{골반고정 Pelvic Stabilization}

골반골절 환자에서 출혈이 발생하는 주요 부위는 대부분 해면골 골절면과 천골앞(presacral) 또는 방광 주변(paravesical)의 정맥총이며, 약 $15 \%$ 정도만 동맥출 혈에서 기인한다고 알려져 있다 (8). 따라서 골반골 골절면을 정복하고 골반 용적을 줄여 주는 것이 효과 적인 지혈에 중요하다 (9). 이를 위한 방법에는 전통 적으로 사용되어 왔던 방법인 침대보(Bed sheet)을 이 용한 방법과 최근에 상품화된 골반 바인더를 이용하 는 방법이 있다. 특히 골반 바인더는 휴대가 간편하고 적용하기가 쉬워 병원 전 단계에서부터 이용되고 있 으며, 조기에 시행된 골반 바인더는 골반용적을 줄여 평균 동맥압의 상승과 삼박수의 안정화를 보이는 등 혈역학적 상태를 개선하는데 효과적이라고 보고되었 다 (5). 따라서 PTLS (Prehospital Trauma Life Support), ATLS (Advanced Trauma Life Support)를 비롯한 여러 가이드라인들에서 혈역학적으로 불안정한 외상환자 에서 골반골절을 의심하고 바인더를 병원 전 단계 또 는 병원단계 초기에 특별한 진단적 검사 없이도 시행 할 것을 추천하고 있다 (10-12). 하지만, 골절유형에 따라 바인더가 출혈과 골절 악화를 초래할 수 있기 때문에 병원 단계에서 골절유형이 진단된 후에도 바 인더를 사용할 것인지에 대해서는 논란이 있다 (8). 또한 주의해야 할 점은 바인더 적용 시 양하지를 내 회전시키고 큰대퇴골기(Great Trochanter) 부위에 바인 더의 중앙이 위치해야 효과적이라는 것과 지속적인 적용 시 압력에 의한 피부궤양을 유발할 수 있으므로 수시로 피부 상태를 확인하거나 적용 후 36 시간 이내 에 제거하여야 한다는 점이다 $(8,10)$.

골반 바인더가 발달하기 전 병원단계에서 주로 사 용되었던 방법으로 외고정(External fixation)과 C-clamp 가 있다. 이들 치료법은 강한 골반 안정성을 가져올 수 있기 때문에 때로는 이것 자체가 근본 치료가 되 기도 한다 $(13,14)$. 하지만 외고정 장치를 적용하기 위해서는 정형외과 전문의가 필요하고 수술실에서 X-ray의 도움을 받아야 하기 때문에 대부분의 외상센 터에서 적용하기에는 제한이 있다 (1). C-clamp는 주 로 유럽의 정형외과 외상 전문의에 의해서 많이 시행 되었는데 이는 골반의 후면에 적용되어 골절을 고정
하며, 필요 시 위아래로 회전이 가능하므로 진단적 개복술이나 혈관조영술을 실시할 때 방해가 되지 않 는 장점이 있다 (1). C-clamp를 조기에 적용하고 추가 적으로 혈관조영술을 시행하였을 때 지혈에 효과적이 었다는 보고가 있다 (15). 하지만 이 역시 정형외과 전문의가 상주하여야 하고 골반의 후면만을 고정할 수 있는 제한점 때문에 유럽을 제외한 미국과 국내에 서는 널리 사용되고 있지는 못한 실정이다.

\section{혈관 조영술 Angioembolization}

미국과 우리나라의 센터들에서 가장 선호되는 지 혈 방법은 혈관조영술 및 색전술이다. 혈관조영술은 90년대 후반부터 여러 가지 장점들로 인해 외상분야 에서 폭 넓게 사용되고 있다 (16). 골반골절 환자의 $\mathrm{CT}$ 검사상 조영제 누출이 발견될 경우 혈관 조영술 에서 치료가 필요한 정도의 출혈이 발견될 가능성은 $75 \%$ 에 이른다고 한다 (17). 또한 출혈성 동반 손상이 있는 경우 혈관조영술을 통해서 골반골절 이외의 출 혈에 대해서도 동시에 지혈 가능하고, 이런 환자에서 는 색전술만으로도 성공적으로 혈역학적 안정이 달성 될 수 있다 (16). 일부에서는 CT 검사상 조영제 누출 이 없는 경우에도 지속적인 혈역학적 불안정성이 관 찰된다면 혈관조영술을 통한 지혈이 필요하다고 주장 하고 있다 (18).

분명 혈관조영술 및 색전술이 효과적인 치료법이 기는 하지만 몇 가지 단점이 지적되고 있다. 우선 혈 관조영술은 동맥출혈에 대해서는 효과적이지만 또다 른 주요 출혈요인인 골절면의 출혈과 정맥출혈은 지 혈할 수가 없다. 두번째로 혈관 조영술을 위해서는 혈관조영장비 뿐만 아니라 인공호흡기, 급속혈액주입 기등이 준비되어 있는 혈관조영실이 항상 준비되어 있어야 하며, 때로는 환자를 멀리 떨어져 있는 혈관 조영실까지 옮겨야 하기 때문에 이에 따른 시간 지체 가 발생할 수 있다. 또한 혈관 조영술을 위해서는 영상 의학과 전문의 등 혈관중재술팀이 필요하다. 미국의 한 Level 1 외상 센터의 보고에 따르면 9년간 내원한 819 명의 골반골절 환자 중 혈관조영술 및 색전술이 필요했던 환자는 31 명 $3.8 \%$ )에 지나지 않았다 (19). 따라서 모든 센터에서 이를 위한 혈관조영실과 전문 의를 대기시키는 것은 현실적으로 불가능하다. 마지 막으로 매우 드물게 보고되고 있지만 둔부 피부괴사 
또는 직장의 허혈성 괴사 등의 합병증이 발생할 수 있다 (20).

\section{외복막 거즈충전술 Extraperitoneal Pelvic Packing (EPP)}

앞에서 서술한 혈관조영술의 제한점들로 인해 대 안으로 제시되고 있는 지혈방법이 외복막 거즈충전술 이다. 거즈충전술은 원래 유럽에서 주로 사용되어 왔 지만 최근 미국의 몇몇 센터에서 거즈충전술로 혈관 조영술을 대체하여 좋은 결과를 얻었다고 보고하고 있다 $(6,21-23)$. 거즈 충전술은 하복부 정중절개를 통 해 복막을 열지 않고 복막 후면을 박리하여 혈종을 제거하고 천골-장골 관절 부위부터 방광주변까지 거 즈를 충전하는 것을 말하며 이는 횡절개를 통해서도 시행할 수 있다. 과거에 시행되어 왔던 복강내거즈 충 전술에 비해 골반내 압박을 효과적으로 가할 수 있고 술기가 어렵지 않아 짧은 시간에 시행할 수 있다 (6). 특히 외상센터에 상주중인 외상외과 전문의에 의해 응급실 또는 소생구역에서도 실시될 수 있어 내원 후 한시간 이내에 대부분 시행할 수 있다. 미국의 덴버 그룹은 거즈 충전술과 골반 고정술을 주요 치료방법 으로 채택하여, 혈역학적으로 불안정한 75 명의 환자 에서 $21 \%$ 의 사망률을 보였다고 보고하여 기존 보고 들에 비해 사망률이 크게 낮아졌다고 하였다 (24). 하 지만, 거즈충전술은 반대로 골절면 및 정맥의 출혈은 줄여 줄 수 있지만 동맥에 대해서는 지혈 효과가 없 으므로 상황에 따라 충전술 전후의 혈관조영술이 필 요할 수 있다.

\section{Resuscitative Endovascular Balloon Occlusion of the Aorta (REBOA)}

외상으로 인한 체간부 출혈 환자에서 혈관 내 기구 를 삽입하여 대동맥 혈류를 차단하려는 시도는 이미 한국전쟁 시기부터 보고된 바 있다 (25). 이후 심한 자궁 출혈이나 대동맥류 파열 환자 등에서 간혹 보고 되어 왔으나 성공적이지는 못하였다 (26). 이라크와 아 프가니스탄 전쟁을 거친 2000년대부터 혈관중재술 기구 의 발전과 함께 외상환자에서 대동맥내 폐색술이 다시 시도되기 시작하였다 (27). 2011년 Stannard 등은 (28) $\mathrm{REBOA}$ 라는 개념을 처음으로 소개하고 세부 테크닉 과 대동맥 구역을 세 구역으로 나누어 제시하였다.
이후 REBOA가 심한 골반골절 환자에게도 보조적인 치료방법으로 제시되어 일부 센터에서는 치료 알고리 즘에 REBOA를 삽입하기도 하였다 (7). 하지만 외상 외과 전문의들의 혈관중재술에 대한 수련 부족과 기 구삽입과 관련된 합병증들에 대한 걱정으로 인해 아 직까지 보편적으로 이용되고 있지는 않다 (29).

\section{가이드라인}

골반골절에 대한 치료 가이드라인은 국가나 센터 마다 다르며, 아직 논란의 여지가 많다. 수십년 전부 터 현재까지 미국과 우리나라에서 골반골절에 있어서 중요한 치료 방법으로 여겨지는 것은 혈관조영술이 다. 하지만 전술한 바와 같이 혈관조영술은 몇가지 단점이 있다. 특히 중재술이 이루어지는 시점까지 걸 리는 시간이 문제가 되는데, 지금까지 보고된 문헌에 따르면 222분에서 466분까지 걸리는 것으로 보고되고 있다 (30-34). 국내에는 거의 보고가 없지만 한 보고 에서 232 분이라고 하였고, 이는 국내의 실정에서 매 우 빠른 편이라고 추정된다 (35). 저자들의 기관에서 조사한 바에 의하면 외상센터 개소 전 268분, 개소 후 141 분 소요되었다. 대량 출혈 환자에서 24 시간 이후 다장기 부전이 주요 사망원인이고 여기에 대량 수혈 이 주요 위험인자 인 것을 고려하면 이는 큰 시간 낭 비일 수 있다.

원래는 유럽에서 사용되어 오던 골반 거즈충전술 을 약간 변형하여 발표한 덴버그룹이 착안한 부분이 바로 시간이다. 외상센터에서는 외상외과 의사가 항 시 대기하고 있으므로 내원 초기에 거즈 충전과 골반 고정을 동시에 시행한다면 출혈량과 수혈량을 줄일 수 있다. 덴버그룹에서 발표한 바에 따르면 거즈충전과 골 반고정을 이용하여 24시간동안 수혈량을 통계적으로 유의하게 현저히 줄일 수 있었고, 이에 따른 사망률도 낮출 수 있었다 $(24,36)$. 최근에는 미국 외 국가의 센 터들에서도 거즈충전술을 포함하는 치료 알고리즘이 좋은 성적을 거두고 있다고 보고하고 있다 (37-41).

하지만 아직도 이런 거즈충전술을 포함한 알고리 즘이 국내뿐 아니라 미국 내에서도 널리 받아들여지 지는 않고 있으며, 미국 내의 외상센터에서도 다양한 치료 알고리즘이 적용되고 있다 (29). 이는 센터마다 가용한 자원의 차이가 있기 때문이다. 일본의 경우 많은 응급의학 의사들이 직접 혈관조영술을 시행 할 
수 있고, 일부에서는 영상의학과 팀이 상주하여 환자 내원 30 분 내에 치료적 중재술을 시행하기도 한다 (42). 이런 경우라면 거즈충전술이 반드시 필요하지 않을 수 있고 혈관조영술 이후 보조적으로 시행될 수도 있다. 따라서 중요한 몇 가지 원칙을 지키면서 각 센터의 자원에 맞추어 치료 방침을 정하고 가이드라인을 도 출해야 할 것이다.

\section{결 론}

불안정한 골반골절 환자의 성공적인 치료를 위해 서는 다학제적 접근이 반드시 필요하고, 특히 외상팀 과 팀리더인 외상외과 전문의의 존재가 매우 중요한 요소이다 (43). 출혈량을 줄이기위한 조치는 병원전 단계부터 중요한데, 특히 적절한 이송병원 선정과, 빠 른 이송, 그리고 골반 바인더 사용이 이루어져야 한 다. 마지막으로 센터의 합의된 알고리즘을 반드시 도 출하고 외상팀 및 전체 의료진이 이를 숙지하고 적절 하게 실행하여야 한다.

\section{CONFLICT OF INTEREST}

No potential conflict of interest relevant to this article was reported.

\section{REFERENCES}

1. Stein D, O'toole R, Scalea T. Multidisciplinary approach for patients with pelvic fractures and hemodynamic instability. Scandinavian Journal of Surgery. 2007;96(4): 272-80.

2. White CE, Hsu JR, Holcomb JB. Haemodynamically unstable pelvic fractures. Injury. 2009;40(10):1023-30.

3. Lustenberger T, Wutzler S, Störmann P, Laurer H, Marzi I. The role of angio-embolization in the acute treatment concept of severe pelvic ring injuries. Injury. 2015;46: S33-S8.

4. Miller PR, Moore PS, Mansell E, Meredith JW, Chang MC. External fixation or arteriogram in bleeding pelvic fracture: initial therapy guided by markers of arterial hemorrhage. Journal of Trauma and Acute Care Surgery. 2003;54(3):437-43.

5. Tan EC, van Stigt SF, van Vugt AB. Effect of a new pelvic stabilizer (T-POD $\left.{ }^{\circledR}\right)$ on reduction of pelvic volume and haemodynamic stability in unstable pelvic fractures. Injury. 2010;41(12):1239-43.
6. Cothren CC, Osborn PM, Moore EE, Morgan SJ, Johnson JL, Smith WR. Preperitonal pelvic packing for hemodynamically unstable pelvic fractures: a paradigm shift. Journal of Trauma and Acute Care Surgery. 2007;62(4):834-42.

7. Brenner ML, Moore LJ, DuBose JJ, Tyson GH, McNutt MK, Albarado RP, et al. A clinical series of resuscitative endovascular balloon occlusion of the aorta for hemorrhage control and resuscitation. Journal of Trauma and Acute Care Surgery. 2013;75(3):506-11.

8. Stahel PF, Mauffrey C, Smith WR, McKean J, Hao J, Burlew $\mathrm{CC}$, et al. External fixation for acute pelvic ring injuries: decision making and technical options. Journal of Trauma and Acute Care Surgery. 2013;75(5):882-7.

9. Scaglione M, Parchi P, Digrandi G, Latessa M, Guido G. External fixation in pelvic fractures. Musculoskeletal surgery. 2010;94(2):63-70.

10. Scott I, Porter K, Laird C, Greaves I, Bloch M. The prehospital management of pelvic fractures: initial consensus statement. Emergency Medicine Journal. 2013; 30(12):1070-2.

11. Cullinane DC, Schiller HJ, Zielinski MD, Bilaniuk JW, Collier BR, Como J, et al. Eastern Association for the Surgery of Trauma practice management guidelines for hemorrhage in pelvic fracture-update and systematic review. Journal of Trauma and Acute Care Surgery. 2011; 71(6):1850-68.

12. Trauma ACoSCo. ATLS, advanced trauma life support for doctors: student course manual: American college of surgeons; 2008.

13. Mason W, Khan S, James C, Chesser T, Ward A. Complications of temporary and definitive external fixation of pelvic ring injuries. Injury. 2005;36(5):599-604.

14. Taeger G, Ruchholtz S, Waydhas C, Lewan U, Schmidt B, Nast-Kolb D. Damage control orthopedics in patients with multiple injuries is effective, time saving, and safe. Journal of Trauma and Acute Care Surgery. 2005;59(2): 408-15.

15. Sadri H, Nguyen-Tang T, Stern R, Hoffmeyer P, Peter R. Control of severe hemorrhage using C-clamp and arterial embolization in hemodynamically unstable patients with pelvic ring disruption. Archives of orthopaedic and trauma surgery. 2005;125(7):443-7.

16. Velmahos GC, Chahwan S, Falabella A, Hanks SE, Demetriades D. Angiographic embolization for intraperitoneal and retroperitoneal injuries. World journal of surgery. 2000;24(5):539-45.

17. Flint L, Cryer HG. Pelvic fracture: the last 50 years. Journal of Trauma and Acute Care Surgery. 2010;69(3): 483-8. 
18. Brown CV, Kasotakis G, Wilcox A, Rhee P, Salim A, Demetriades D. Does pelvic hematoma on admission computed tomography predict active bleeding at angiography for pelvic fracture? The American Surgeon. 2005;71(9): 759-62.

19. Costantini TW, Bosarge PL, Fortlage D, Bansal V, Coimbra R. Arterial embolization for pelvic fractures after blunt trauma: are we all talk? The American Journal of Surgery. 2010;200(6):752-8.

20. Hornez E. Management of exsanguinating pelvic trauma: do we still need the radiologist? Journal of visceral surgery. 2011;148(5):e379-e84.

21. Smith WR, Moore EE, Osborn P, Agudelo JF, Morgan SJ, Parekh AA, et al. Retroperitoneal packing as a resuscitation technique for hemodynamically unstable patients with pelvic fractures: report of two representative cases and a description of technique. Journal of Trauma and Acute Care Surgery. 2005;59(6):1510-4.

22. Ertel W, Keel M, Eid K, Platz A, Trentz O. Control of severe hemorrhage using C-clamp and pelvic packing in multiply injured patients with pelvic ring disruption. Journal of Orthopaedic Trauma. 2001;15(7):468-74.

23. Tötterman A, Madsen JE, Skaga NO, Røise O. Extraperitoneal pelvic packing: a salvage procedure to control massive traumatic pelvic hemorrhage. Journal of Trauma and Acute Care Surgery. 2007;62(4):843-52.

24. Burlew CC, Moore EE, Smith WR, Johnson JL, Biffl WL, Barnett CC, et al. Preperitoneal pelvic packing/external fixation with secondary angioembolization: optimal care for life-threatening hemorrhage from unstable pelvic fractures. Journal of the American College of Surgeons. 2011;212(4):628-35.

25. Hughes $\mathrm{CW}$. Use of an intra-aortic balloon catheter tamponade for controlling intra-abdominal hemorrhage in man. Surgery. 1954;36(1):65-8.

26. Belenkiy SM, Batchinsky AI, Rasmussen TE, Cancio LC. Resuscitative endovascular balloon occlusion of the aorta for hemorrhage control: Past, present, and future. Journal of Trauma and Acute Care Surgery. 2015;79(4):S236-S42.

27. Martinelli T, Thony F, Decléty P, Sengel C, Broux C, Tonetti $\mathrm{J}$, et al. Intra-aortic balloon occlusion to salvage patients with life-threatening hemorrhagic shocks from pelvic fractures. Journal of Trauma and Acute Care Surgery. 2010;68(4):942-8.

28. Stannard A, Eliason JL, Rasmussen TE. Resuscitative endovascular balloon occlusion of the aorta (REBOA) as an adjunct for hemorrhagic shock. Journal of Trauma and Acute Care Surgery. 2011;71(6):1869-72.

29. Costantini TW, Coimbra R, Holcomb JB, Podbielski JM,
Catalano R, Blackburn A, et al. Current management of hemorrhage from severe pelvic fractures: Results of an American Association for the Surgery of Trauma multi-institutional trial. Journal of Trauma and Acute Care Surgery. 2016;80(5):717-25.

30. Perez J, Hughes T, Bowers K. Angiographic embolisation in pelvic fracture. Injury. 1998;29(3):187-91.

31. Hamill J, Holden A, Paice R, Civil I. Pelvic fracture pattern predicts pelvic arterial haemorrhage. Australian and New Zealand Journal of Surgery. 2000;70(5):338-43.

32. Cook R, Keating J, Gillespie I. The role of angiography in the management of haemorrhage from major fractures of the pelvis. Bone \& Joint Journal. 2002;84(2):178-82.

33. Fangio P, Asehnoune K, Edouard A, Smail N, Benhamou D. Early embolization and vasopressor administration for management of life-threatening hemorrhage from pelvic fracture. Journal of Trauma-Injury Infection and Critical Care. 2005;58(5):978-84.

34. Fang J-F, Shih L-Y, Wong Y-C, Lin B-C, Hsu Y-P. Repeat transcatheter arterial embolization for the management of pelvic arterial hemorrhage. Journal of Trauma and Acute Care Surgery. 2009;66(2):429-35.

35. Lee YJ, Jae HJ, Cha WC, Seo JS, Kim HC, Shin CI, et al. Treatment Strategy of Transcatheter Arterial Embolization after Pelvic CT Angiography in Traumatic Pelvic Hemorrhage: A Single Regional Emergency Center's Experience. Journal of the Korean Society of Traumatology. 2009;22(2):184-92.

36. Osborn PM, Smith WR, Moore EE, Cothren CC, Morgan $\mathrm{SJ}$, Williams $\mathrm{AE}$, et al. Direct retroperitoneal pelvic packing versus pelvic angiography: a comparison of two management protocols for haemodynamically unstable pelvic fractures. Injury. 2009;40(1):54-60.

37. Cheng M, Cheung M-T, Lee K-Y, Lee K-B, Chan S-CH, $\mathrm{Wu} \mathrm{A}-\mathrm{CY}$, et al. Improvement in institutional protocols leads to decreased mortality in patients with haemodynamically unstable pelvic fractures. Emergency Medicine Journal. 2015;32(3):214-20.

38. Black SR, Sathy AK, Jo C, Wiley MR, Minei JP, Starr AJ. Improved Survival After Pelvic Fracture: 13-Year Experience at a Single Trauma Center Using a Multidisciplinary Institutional Protocol. Journal of Orthopaedic Trauma. 2016;30(1):22-8.

39. Chiara O, di Fratta E, Mariani A, Michaela B, Prestini L, Sammartano F, et al. Efficacy of extra-peritoneal pelvic packing in hemodynamically unstable pelvic fractures, a Propensity Score Analysis. World Journal of Emergency Surgery. 2016;11(1):1.

40. Jang JY, Shim H, Jung PY, Kim S, Bae KS. Preperitoneal 
pelvic packing in patients with hemodynamic instability due to severe pelvic fracture: early experience in a Korean trauma center. Scandinavian journal of trauma, resuscitation and emergency medicine. 2016;24(1):1.

41. Li Q, Dong J, Yang Y, Wang G, Wang Y, Liu P, et al. Retroperitoneal packing or angioembolization for haemorrhage control of pelvic fractures-Quasi-randomized clinical trial of 56 haemodynamically unstable patients with Injury Severity Score $\geq$ 33. Injury. 2016;47(2):395-401.

42. Matsumoto J, Lohman B, Morimoto K, Ichinose Y, Hattori
T, Taira Y. Damage control interventional radiology(DCIR) in prompt and rapid endovascular strategies in trauma occasions (PRESTO): a new paradigm. Diagnostic and interventional imaging. 2015;96(7):687-91.

43. Shin S, Kyung KH, Kim JW, Kim JJ, Hong SK. The importance of the trauma surgeon: A reflection on the management of hemodynamically unstable pelvic trauma patients. Journal of the Korean Society of Traumatology. 2009;22(2):254-9. 